\title{
FUNGSI FORUM KERUKUNAN UMAT BERAGAMA (FKUB) DALAM SISTEM SOSIAL PENCIPTAAN KERUKUNAN UMAT BERAGAMA DI KABUPATEN PASAMAN BARAT
}

\author{
Ferdi Ferdian \\ Department of Sociology, Faculty of Social and Political Science, Andalas University \\ e-mail: eljanma.ferdi@gmail.com \\ Afrizal \\ Department of Sociology, Faculty of Social and Political Science, Andalas University \\ e-mail:afrizal_2002au@yahoo.com \\ Elfitra \\ Department of Sociology, Faculty of Social and Political Science, Andalas University \\ e-mail:elbaiko69@gmail.com
}

Diterima: 12 Agustus $2018 \quad$ Direvisi : 30 September 2018

Diterbitkan: 31 Desember 2018

\begin{abstract}
This article is about the establishment of tolerance between groups of religious followers at the regencey level. FKUB, which means the forum for religious harmony, have been established since 2006 to maintain the religious harmony among different religious followers in Indonesia. The forum was formed after a joint policy between the Minister of Religious Affairs and the Minister of Internal Affairs. The joint policy was constructed based on the view that the governmental effort on facilitating communication and dialog between different religious leaders will prevent the horizontal conflict between religious followers. This paper is aimed to investigate the FKUB's role in establishing tolerance between groups of the religious followers in West Pasaman Regency. This paper is mainly focused on investigating the activities organized to maintain the interreligious harmony in the regency. By using indepth interview technique and the Functional Structural Theory are used and implemented to portray the contribution of FKUB to the establishment of the religious harmony. It is found that FKUB conducts various activities in playing their role, that are facilitating a series of dialogue between religious groups and community leaders and conducting investigations and mediations as they are needed. FKUB of West Pasaman Regency integrate itself to the social system of the community which allow them to manage the inter-religious harmony in West Pasaman.
\end{abstract}

Keywords: tolerance between religious adherents, religious harmony, FKUB, mediation, religious conflicts

\begin{abstract}
Abstrak
Artikel ini adalah tentang penciptaan toleransi antar pemeluk agama pada tingkat kabupaten. Forum Kerukunan Ummat Beragama (FKUB) mulai dari tingkat nasional sampai pada tingkat kabupaten/ kota didirikan oleh pemerintah setelah reformasi (2006) untuk menciptakan kerukunan umat beragama di Indonesia. Kebijakan ini merupakan kebijakan bersama Menteri Agama dan Menteri Dalam Negeri didasarkan pada pandangan bahwa konflik-konflik agama yang terjadi dapat dikendalikan dengan mewadahi komunikasi antar pemuka-pemuka agama yang berbeda. Artikel ini akan menyampaikan hasil penelitian tentang fungsi FKUB menciptakan toleransi antar umat bergama di Kabupaten Pasaman Barat, yang terdiri dari pemeluk agama yang berbeda. Fokus penelitian pada aktivitas-aktivitas yang dilakukan untuk menjaga kerukunan antar umat beragama di Kabupaten Pasaman Barat. Dengan menggunakan teknik wawancara mendalam dan Teori Struktural Fungsional, artikel ini akan menunjukkan bahwa untuk menciptakan kerukunan antar umat beragama FKUB Pasaman Barat melakukan berbagai kegiatan yakni melakukan dialog dengan tokoh agama dan tokoh masyarakat, menampung dan menyalurkan aspirasi masyarakat, melakukan investigasi dan mediasi. Dalam melakukan berbagai aktivitas-aktivitas, FKUB Pasaman Barat menduduki posisi integrasi dalam sistem sosial kerukunan beragama di Kabupaten Pasaman Barat dan memainkan peranan sebagai penjaga kerukunan antar umat beragama.
\end{abstract}

Kata Kunci: toleransi antar pemeluk agama, kerukunan umat beragama, FKUB, mediasi, konflik-konflik agama 


\section{Latar Belakang}

Indonesia sebagai negara kesatuan, pada dasarnya berpotensi atau rawan munculnya pertentangan karena keragaman suku bangsa, bahasa, agama, ras dan etnis dan golongan yang hadir di tengah kehidupan masyarakat. Keragaman inilah yang kemudian kerap menjadi pemicu timbulnya pertentangan sosial di tengah masyarakat. Semakin marak dan meluasnya pertentangan akhir-akhir ini adalah suatu pertanda menurunnya toleransi di dalam masyarakat. Kondisi seperti ini terlihat dengan meningkatnya pertentangan bernuanasa SARA serta munculnya sejumlah gerakan yang 'seolah ingin memisahkan diri dari NKRI akibat ketidakpuasan dan perbedaan kepentingan. Apabila kondisi ini tidak segera ditangani dan dikelola secra baik, maka tidak menutup kemungkinan akan berdampak pada disintegrasi bangsa. Terlebih lagi penelitian Geertz yang mengungkapkan bahwa kemajemukan bangsa Indonesia sudah terbagibagi ke dalam subsistem yang kurang lebih berdiri sendiri-sendiri, yang masing-masingnya terikat pada satu ikatan dan semangat primodial yang kuat.

Bangsa Indonesia dengan masyarakatnya yang beragam berpotensi dan sangat rentan terhadap kekerasan etnik, baik dikontruksi secara kultural maupun politik. Bila entitas agama atau elemen primodial lain muncul di pentas politik sebagai prinsip paling dominan dalam pengaturan negara dan bangsa, apalagi berkeinginan merubah sistem yang selama ini berlaku, bukan tidak mungkin ancaman disintegrasi bangsa dapat terjadi di Indonesia.

Sejalan dengan itu, Setiadi \& Kolip menilai bahwa di dalam struktur masyarakat majemuk biasanya menyimpan benih-benih pertentangan yang lazim disebut konflik laten. Konflik ini berawal dari perbedaan pandangan, langkah, dan pemahaman dan benturanbenturan antar-kelompok maupun antarindividu. Konflik akan terjadi jika permasalahan yang muncul dipermukaan tidak menemukan titik penyelesaian, maka akan berujung pada kekerasan fisik antara pihakpihak yang bertikai. ${ }^{1}$

Ada beberapa catatan peristiwa kekerasan yang pernah terjadi di negeri ini, seperti kerusuhan di Situbondo pada Oktober 1996. Kerusuhan serupa juga terjadi di Tasikmalaya pada penghujung tahun 1996. Sebelumnya (1990), ketika masa Islam tersinggung dengan aktifitas Arswendo Atmodiloto yang mengadakan kuis yang me-rengking Nabi di Tabloid Monitor yang hasilnya dianggap melecehkan ummat Islam tahun 1996. Kemudian pada awal 1997 konflik yang serupa pecah di Rengasdengklok. Tahun 1998 pecah Insiden Ketapang yang kemudian berlanjut pada tragedi Ketapang. Pada tahun yang sama, bertepatan dengan Hari Raya Idul Fitri Insiden Ambon pecah. Sebagai kelanjutan dari konflik ini terjadi pertikaian antar-agama di Halmahera dan Poso. Dalam demonstrasi mahasiswa terjadi pelecehan (membuang najis) di masjid DPR Tk-I Provinsi Sumatera Utara Tahun 1999, dan pada 28 Mei 2000 terjadi pengeboman terhadap rumah-rumah ibadah di Medan. $^{2}$

Selain kejadian di atas masih terjadi juga kasus keagamaan lain, diantaranya : (1) Pada Tahun 2012, penyerangan terhadap kelompok Muslim Syi'ah di Dusun Nanggernang Desa Karang Gayam Kecamatan Omben Sampang Madura. Akibat peristiwa ini seorang warga dinyatakan tewas, 5 orang luka-luka dan 4 diantara korban luka dalam kondisi kritis. Selain menyerang dan melukai warga, kelompok penyerang juga membakar rumahrumah pngikut Syi'ah yang ada di dua desa yaitu Desa Karang Gayam dan Desa Bluuran

${ }^{1}$ Setiadi, Elly M dan Kolip, Usman. 2011.

Pengantar Sosiologi "Pemahaman Fakta dan Gejala Permasalaban Sosial: Teori, Aplikasi dan Pemecahannya. (Jakarta: Kencana Prenada Media Goup) h.566.

2 Harahap, Syahrin. 2011. Teologi Kerukunan (Jakarta: Prenada) hal.84-85. 
Kecamatan Omben, Sampang;

Pembakaran Gereja di Aceh Singkil 13 Oktober 2015. Menurut kepolisian motif peristiwa tersebut berkaitan dengan unsur politis yaitu pemilihan kepala daerah namun unsur sentimen agama menjadi isu sentral yang melatarbelakangi pecahnya konflik. Hal ini terlihat ketika amarah warga dilampiaskan dengan perusakan gereja. Pada konflik/kekerasan sosial ini, kepolisian menetapkan 10 tersangka dalam peristiwa bentrokan antar warga di Aceh Singkil; (3) Konflik/kekerasan sosial Tolikara pada 17 Juli 2015. Jemaah Kristen Gidi yang sedang melakukan kegiatan seminar internasional membubarkan jemaah Islam yang sedang melaksanakan shalat Idul Fitri. Selain membubarkan terjadi juga pelemparan batu sehingga terjadilah bentrok antar kedua jemaah; (4) Konflik Sara di Tanjung Balai Asahan pada 30 Juli 2016. Penyebab konflik adalah seorang wanita keturunan Tionghoa yang mengajukan protes pada takmir Masjid Al Makhsum untuk mengecilkan volume suara azan di Masjid karena merasa terganggu. Ekses dari peristiwa tersebut, telah terjadi pembakaran 2 Vihara dan 5 Klenteng. ${ }^{3}$

Keragaman agama menjadi salah satu realitas yang selalu mewarnai nuansa kehidupan bermasyarakat di Indonesia. Kesadaran terhadap keragaman itu, khususnya keragaman agama menjadi titik tolak kemerdekaan beragama setiap manusia. Bahkan Natsir dalam Faisal menegaskan bahwa "agama menempati posisi yang urgen, vital dan strategis dalam kehidupan manusia". Agama lebih lanjut diposisikan sebagai tolak ukur dan kriteria dalam menentukan sesuatu yang salah atau benar, sehingga keragaman agama, di samping sebagai realitas pada tataran

\footnotetext{
3 Syukron, Buyung, Agama dalam Pusaran Konflik, Studi Analisis Resolusi terbadap Munculnya Kekerasan Sosial Berbasis Agama di Indonesia, Ri'ayah, Vol. 02, No.01 Januari-Juni 2017, h. 7-10
}

konseptual normatif-teologis, juga merupakan realitas di tataran empiris sosiologis-politis. Kedua dimensi ini tidak bisa terpisahkan, mengingat agama merupakan sistem norma yang telah mengejawantah dalam kehidupan tiap-tiap ummat beragama, sehingga untuk menciptakan persatuan dan kesatauan bangsa, maka kerukunan antar ummat beragama ini menjadi pilar penting yang perlu dikelola secara serius. ${ }^{4}$

Peristiwa-peristiwa pertentangan yang telah atau akan terjadi mesti dikelola dengan baik sehingga terciptanya kerukunan. Dan demi merawat kerukunan, Soepomo dalam Dawam berpendapat bahwa UUD 1945 adalah sebuah konstitusi gotong royong. Sedangkan dalam Pasal 33 UUD 1945, sistem ekonomi Indonesia disebut sebagai berasaskan kekeluargaan. Nilai dari sila Ketuhanan Yang Maha Esa, kekeluargaan dan gotong royong adalah faktor persatuan masyarakat yang meredam pertentangan dalam masyarakat yang beragam. Keberagaman pada bhinneka tunggal ika, mengharuskan lahirnya harmoni atau keseimbangan. Didalamnya terkandung unsur moderasi yang dalam ajaran Islam disebut sebagai "pertengahan" (wasathiayyat al-Islam) yang berintikan keadilan. Sikap moderasi yang bersifat meredam pertentangan itu, melahirkan prinsip pertengahan yang berintikan keadilan. Dan keadilan itulah yang melahirkan harmoni yang berisikan keserasian dan keseimbangan. Karena itulah dalam pembukaan UUD 1945, aksiologi negara RI, yaitu perdamaian abadi, didasarkan keadilan sosial. Karena keadilan sosial itulah yang mampu meredam potensi konflik dan menciptakan perdamaian. ${ }^{5}$

Selain itu, sejumlah peraturan pemerintah yang menyangkut pembinaan kerukunan

${ }^{4}$ Faisal. 2016. Hubungan Antar Agama; Hubungan Islam Kristen Menurut Mubammad Natsir. (Padang: Hayfa Press) h.97

5 Raharjo, M. Dawam. 2010. Merayakan Kemajemukan Kebebasan dan Kebangsaan Jakarta: Kencana) hal.192. 
ummat beragama berbasis kesadaran masyarakat dan pembentukan Forum Kerukunan Umat Beragama (FKUB) juga dijadikan sebagai sarana pemersatu masyarakat yang beragam tersebut. Dalam hal ini, FKUB terlihat menjadi sebuah langkah strategis yang dilakukan oleh pemerintah dalam membangun, membimbing, dan memelihara kerukunan antar ummat beragama baik di tingkat nasional, propinsi maupun tingkat kabupaten/kota di Indonesia sebagaimana Peraturan Bersama Menteri Agama dan Menteri Dalam Negeri Nomor 9 dan 8 tahun $2006 .{ }^{6}$

Setidaknya ada beberapa kasus keagamaan yang berhasil diselesaikan oleh FKUB, diantaranya: (1) Kasus pembakaran mesjid di Tolikara tahun 2015. Kasus ini terjadi bertepatan dengan pelaksanaan shalat idul fitri $1436 \mathrm{H}$, dimana ini terjadi karena adanya ketegangan antara umat Gereja Injil Di Indonesia (GIDI) Tolikara dengan umat islam di Tolikara. Kasus yang menjadi isu nasional inipun mendapatkan respon dari banyak pihak, mulai dari pemerintah daerah, pemerintah pusat seperti TNI, Polri, Menteri terkait, bahkan hingga presiden bereaksi. Selain itu, FKUB Papua, sebagai lembaga dengan misi kerukunan umat beragama memainkan perananan yang sangat signifikan dalam kasus ini, diantaranta membuat Tim Khusus Pencari Fakta Dan Data Insiden Tolikara, menjadi fasilitator/ mediator mendamaikan kedua belah pihak yang berpekara sehingga pada tanggal 29 Juli 2015 lahirlah Kesepakatan Bersama untuk kerukunan dan perdamaian guna merengkuh kedamaian dan kerukunan. (Laporan Data dan Fakta Insiden Tolikara 11 Juli 2015 oleh FKUB Propinsi Papua); (2) Pembakaran gereja tahun 2016 di Aceh Singkil, pada insiden ini FKUB Aceh Singkil melakukan upaya pendamaian antara pihak muslim dan kristen dengan menjadi mediator

${ }^{6}$ Ibid, hal.6-7. dan mencari solusi terbaik yang juga dibantu oleh pihak pemerintah daerah, pihak kepolisian dan para tooh agama dan masyarakat, sekaligus FKUB juga mensosialisasikan peraturan Menteri Bersama No 9 dan No 8 tahun 2006 tentang aturan pendirian rumah ibadah.

Pasaman Barat yang termasuk salah satu kabupaten di provinsi Sumatera Barat yang memiliki keberagaman secara etnik, agama dan budaya. BPS (Badan Pusat Statistik) Pasaman Barat mencatat terdapat enam (6) etnik masyarakat, yaitu Minangkabau, Batak, Mandailing, Jawa, Melayu dan Nias. Mereka hidup dan mendiami Pasaman Barat secara bersamaan dengan menjadikan salah satu agama -Islam, Protestan, Katolik atau Hindusebagai keyakinan mereka dalam menjalankan kehidupan. ${ }^{7}$ Kondisi ini menunjukkan bahwa masyarakat Pasaman Barat tergolong sebagai masyarakat majemuk, heterogen dan plural, sebagaimana Furnival dalam Nasikun, menjelaskan bahwa masyarakat multikultur adalah masyarakat yang terdiri dari dua atau lebih elemen yang hidup secara berdampingan dalam satu entitas sosial. ${ }^{8}$

Berikut ini jumlah penduduk Kabupaten Pasaman Barat berdasarkan agama di tiap kecamatan :

Tabel 1. Jumlah Penduduk berdasarkan agama di Pasaman Barat

\begin{tabular}{|c|c|c|c|c|c|c|}
\hline No & $\begin{array}{l}\text { Keca } \\
\text { Matan }\end{array}$ & Islam & $\begin{array}{l}\text { Prote } \\
\text { stan }\end{array}$ & $\begin{array}{l}\text { Bud } \\
\text { ha }\end{array}$ & $\begin{array}{l}\text { Kato- } \\
\text { lik }\end{array}$ & $\mathrm{Jml}$ \\
\hline 1 & $\begin{array}{l}\text { Gunung } \\
\text { Tuleh }\end{array}$ & $\begin{array}{l}21.21 \\
9\end{array}$ & - & - & - & $\begin{array}{l}21.2 \\
19\end{array}$ \\
\hline 2 & Kinali & $\begin{array}{l}70.39 \\
3\end{array}$ & 687 & - & $\begin{array}{l}1.16 \\
5\end{array}$ & $\begin{array}{l}72.2 \\
45\end{array}$ \\
\hline 3 & Pasaman & $\begin{array}{l}75.12 \\
7\end{array}$ & - & - & - & $\begin{array}{l}75.1 \\
27\end{array}$ \\
\hline 4 & $\begin{array}{l}\text { Lembah } \\
\text { Melintang }\end{array}$ & $\begin{array}{l}47.85 \\
2\end{array}$ & 29 & - & 10 & $\begin{array}{l}47.8 \\
91\end{array}$ \\
\hline 5 & Sungai & 25.20 & 10 & - & 10 & 25.2 \\
\hline
\end{tabular}

7 BPS Pasaman Barat. 2017. Pasaman Barat dalam Angka (Padang: CV. Zigiran) hal.124.

${ }^{8}$ Nasikun. 2014. Sistem Sosial Indonesia. (Jakarta: RajaGrafindo Persada) hal.39-40 


\begin{tabular}{|c|c|c|c|c|c|c|}
\hline & Beremas & 5 & & & & 25 \\
\hline 6 & $\begin{array}{l}\text { Ranah } \\
\text { Betahan }\end{array}$ & $\begin{array}{l}26.43 \\
8\end{array}$ & - & - & - & $\begin{array}{l}26.4 \\
38\end{array}$ \\
\hline 7 & Talamau & $\begin{array}{l}26.92 \\
2\end{array}$ & - & - & - & $\begin{array}{l}26.9 \\
22\end{array}$ \\
\hline 8 & $\begin{array}{l}\text { Sasak } \\
\text { Ranah } \\
\text { Pesisir }\end{array}$ & $\begin{array}{l}14.66 \\
7\end{array}$ & - & - & 19 & $\begin{array}{l}14.6 \\
86\end{array}$ \\
\hline 9 & $\begin{array}{l}\text { Sungai } \\
\text { Aur }\end{array}$ & $\begin{array}{l}36.17 \\
1\end{array}$ & 113 & 76 & 179 & $\begin{array}{l}36.5 \\
39\end{array}$ \\
\hline $\begin{array}{l}1 \\
0\end{array}$ & $\begin{array}{l}\text { Koto } \\
\text { Balingka }\end{array}$ & $\begin{array}{l}29.83 \\
8\end{array}$ & 32 & - & 8 & $\begin{array}{l}29.8 \\
78\end{array}$ \\
\hline $\begin{array}{l}1 \\
1\end{array}$ & $\begin{array}{l}\text { Luhak } \\
\text { Nan Duo }\end{array}$ & $\begin{array}{l}40.82 \\
6\end{array}$ & 724 & - & $\begin{array}{l}1.06 \\
5\end{array}$ & $\begin{array}{l}42.6 \\
15\end{array}$ \\
\hline & Jumlah & $\begin{array}{l}414.6 \\
58\end{array}$ & 1.595 & 76 & $\begin{array}{l}2.45 \\
6\end{array}$ & $\begin{array}{l}418 . \\
785\end{array}$ \\
\hline
\end{tabular}

Sumber: Data BPS; Pasaman Barat Dalam Angka Tabun 2017

"Keragaman etnik dan agama tersebut bukan tidak dapat berpeluang menciptakan perselisihan dan persengketaan, yang pada akhirnya bisa berujung pada kekerasan di tengah masyarakat. Salah satunya, misalnya terpotret melalui pengrusakan rumah warga yang bermukim di Kecamatan Luhak Nan Duo pada tahun 2012 yang lalu. Rumah tersebut "disulap" menjadi Gereja (tempat Ibadah) karena tempat ibadah terbilang jauh dari kediaman mereka, sehingga kejadian itu memicu kemarahan bagi ummat Islam, yang pada akhirnya mereka membongkarpaksa salib yang terpasang di luar rumah dan menyegel rumah tersebut. Selain itu, pada tahun 2014 juga terjadi pembakaran dua buah Gereja yang terletak di Kecamatan Kinali dalam waktu yang bersamaan, yaitu Gereja St. Maria diangkat Ke Surga dan Gereja Theresia. Hingga saat ini, belum diketahui siapa oknum yang melakukan pembakaran tersebut, dan pihak FKUB Pasaman Barat dengan cepat menyelesaikan insiden ini".?

9 Alam, Alman Gampo, Wawancara Pribadi, Kamis 24 Agustus 2017.
Kejadian ini menjadi alasan yang memperkuat bahwa perbedaan agama dan keyakinan menjadi salah satu penyebab pertentangan di tengah masyarakat yang plural. Sehingga setelah diterbitkannya Peraturan Bersama Menteri Agama dan Menteri Dalam Negeri Nomor 9 dan 8 Tahun 2006, Pemerintah Pasaman Barat bergegas membentuk suatu wadah kerukunan antar ummat beragama yang diberi nama Forum Kerukunan Ummat Beragama (FKUB) Pasaman Barat. FKUB Pasaman Barat berdiri sejak tanggal 08 Januari 2007 berdasarkan SK Bupati Nomor 188.45/04/BUP_ PASBAR/2007 sesuai dengan amanah PBM, yaitu sebagai wadah para tokoh agama dalam mewujudkan persatuan dan kerukunan antar ummat beragama dan demi menyukseskan pembangunan masyarakat di Kabupaten Pasaman Barat.

Penelitian Ropi (2014) dengan judul Implementasi Peraturan Pendirian Rumah Ibadah (Studi Evaluasi Kebijakan Kerukunan Umat Beragama di Kecamatan Jatiasih Kota Bekasi 20062014). Peneitian ini menemukan bahwa problematika utama dari ketidakefektifan peraturan tersebut disebabkan oleh kurang intensifnya sosialisasi peraturan tersebut sendiri dan kurang tegasnya aparatur pemerintah dalam menyelesaikan permasalahan rumah ibadat di wilayah kecamatan Jatiasih Kota Bekasi, akibatnya banyak terdapat ruko-ruko dan ruma tinggal tunggal yang dijadikan sebagai tempat ibadah publik. Hal ini menjadi pemicu terjadinya konflik dan perselisihan antar umat beragama.

Selanjutnya penelitian Ghali (2016) yang berjudul Peran Komunikasi Pengurus Forum Kerukunan Umat Beragama (FKUB) Dalam Mengatasi Konflik Antarumat Beragama. Hasil penelitian menunjukkan bahwa bentuk komunikasi yang dipakai pengurus FKUB dalam mengatasi konflik antarumat beragama di Kabupaten Aceh Singkil yaitu komunikasi 
antarpribadi, komunikasi publik, dan komunikasi massa. Sedangkan metode komunikasi yang digunakan adalah monitoring atau penyuluhan agama ke setiap masyarakat, menjalin kerjasama dengan pemerintah daerah, kepolisian dan pendekatan ormas-ormas keagamaan yang ada di Aceh Singkil. Disamping itu hambatan komunikasi yang terjadi karena pengurus FKUB Aceh Singkil sangat minim dengan wilayah Aceh Singkil yang sangat luas dalam menjalankan tugas dan fungsinya dan lambatnya kebijakan pemerintah dalam mengambil keputusan ketika rumah ibadah ditemukan tidak memiliki surat izin, sehingga menimbukan konflik.

Berbeda dengan penelitian sebelumnya, penelitian ini mengkaji tentang fungsi Forum Kerukunan Umat Beragama (FKUB) dalam sistem sosial penciptaan kerukunan umat beragama di Kabupaten Pasaman Barat.

\section{Melakukan dialog dengan tokoh agama dan tokoh masyarakat}

Kegiatan ini dihadiri oleh para tokoh agama seperti ustadz, pastor, ulama dan pengurus FKUB Pasaman Barat yang berjumlah 12 orang dimana terdiri dari ketua, wakil ketua, sekretaris, koordinator bidang pendirian rumah ibadah, koordinator pemeliharaan kerukunan umat beragama, koordinator bidang pemberdayaan kerukunan umat beragama, koordinator bidang penyuluhan kerukunan umat beragama dan anggota-anggota. Susunan pengurus FKUB Pasaman Barat juga merupakan pemuka agama yang berasal dari masing-masing agama di Pasaman Barat seperti Islam, Katolik dan Protestan. Sedangkan tokoh masyarakat yang dimaksud seperti niniak mamak, bundo kanduang, pihak kepolisian serta pihak Dandim.

Kegiatan ini biasanya dilaksanakan sekali dalam satu tahun di Aula Kakanmenag Pasaman Barat. Artinya kegiatan dialog difasilitasi oleh Kesbangpol dan begitu juga dengan anggarannya. Kegiatan ini berlangsung 2-4 jam dalam satu hari. Persoalan-persoalan yang dibahas dalam dialog adalah terkait isuisu keagamaan yang terjadi di tengah masyarakat.

Di dalam kegiatan dialog para tokoh agama, tokoh masyarakat beserta pengurus FKUB Pasaman Barat menyampaikan laporan perkembangan kehidupan keagamaan dari masing-masing pemuka agama, menyampaikan kasus yang diterima dari laporan masyarakat khususnya persoalan agama, mencari solusi atau langkah-langkah terhadap persoalan agama yang diterima dan langkah-langkah menjaga kerukunan umat beragama di Pasaman Barat. Salah satu contohnya mengenai langkah-langkah antisipatif untuk kelancaran jalannya perayaan hari raya masingmasing agama di Pasaman Barat.

Salah satu cara yang disepakati untuk kelancaran perayaan masing-masing agama di Pasaman Barat adalah pengamanan yang dilakukan oleh pemuda Muslim terhadap gereja saat perayaan hari raya Agama Kristen, di mana umat Kristen sedang melakukan ibadah. Begitupun sebaliknya adanya pengamanan oleh pemuda umat Kristen terhadap umat Muslim saat hari raya Idul Fitri dan Idul Adha disekitar mesjid saat melaksanakan ibadah.

"Di ujung dialog adanya solusi yang ditawarkan dan akan dilakukan di lapangan. Contohnya membahas tentang mencegah terjadinya konflik agama saat hari raya besar agama seperti natal dan hari raya idul Fitri dan Idul Adha. Waktu itu disepakati dilakukan pengamanan oleh pemuda Muslim terhadap gereja saat hari raya agama Kristen dan sebaliknya pemuda Kristen melakukan pengamanan saat jamaah Muslim merayakan hari 
raya Idul Fitri dan Idul Adha". ${ }^{10}$

Contoh lainnya seperti pendirian rumah ibadah di Giri Maju Koto Baru Plasma V yang didiami suku Batak dan Nias pada tahun 2017. Tokoh agama, tokoh masyarakat beserta pengurus FKUB Pasaman Barat membahas isu-isu tersebut dan menyusun langkah-langkah yang dilakukan. Adapun bentuk kesepakatan untuk permasalah ini adalah memberhentikan pendirian rumah ibadah karena terjadinya gejolak dari masyarakat sekitar yang memprotes pendirian rumah ibadah tersebut. Selain itu juga karena tidak memenuhi persyaratan pendirian rumah ibadah.

Hasil dari kegiatan dialog adalah berupa kesepahaman antara para tokoh agama maupun tokoh masyarakat Pasaman Barat. Kesepahaman adalah suatu kondisi yang menghasilkan kata sepakat banyak orang dalam suatu keputusan dalam perkara yang diselesaikan oleh para masyarakat yang berhubungan langsung dengan adanya keberadaan. Para tokoh agama dan tokoh masyarakat adalah mereka yang sudah diakui ketokohannya, baik kedalamannya tentang agama yang dianut termasuk juga kedewasaaan dalam kenasionalismean. Hal demikian terbukti dari saling sepakatnya para tokoh agama dan tokoh masyarakat ini untuk saling memupuk rasa kebersamaan dalam bingkai keberagaman, walau berbeda keyakinan tetapi tetap dalam daerah dan negara yang satu.

FKUB diyakini sebagai forum yang mewadahi semua agama yang ada di Pasaman Barat sehingga para tokoh agama, tokoh masyarakat beserta pengurus FKUB juga memandang bahwa FKUB bukan hanya mewadahi agama mayoritas tetapi semua agama yang ada di tengah masyarakat. Kegiatan dialog selalu menyatakan komitmen

\footnotetext{
10 Yondrizal, Wawancara Pribadi, Minggu 8 Juli 2018.
}

bersama dengan peserta yang hadir, bahwa adanya kewajiban untuk mewujudkan negara yang damai.

Dalam menjalankan tugas FKUB Pasaman Barat, kesepahaman tentu menjadi hal yang penting baik bagi para tokoh agama maupun juga pengurus FKUB Pasaman Barat yang memiliki latar belakang yang berbedabeda khususnya agama. Jika tidak adanya kesepahaman maka fungsi FKUB tidak akan berjalan dengan semestinya. Kesepahaman ini juga ditunjukkan dengan adanya koordinasi yang lancar antar tokoh-tokoh agama sehingga terciptanya hubungan yang harmonis dan menghasilkan kesepakatan-kesepakatan demi kerukunan umat beragama. Pesan-pesan kerukunan tersebut juga disampaikan kepada tiap-tiap umat masing-masing tokoh agama.

\section{Menampung dan Menyalurkan Aspirasi Organisasi Keagamaan}

Ormas keagamaan adalah organisasi non pemerintah bervisi kebangsaan yang dibentuk berdasarkan kesamaan agama oleh warga negara Republik Indonesia secara sukarela, berbadan hukum dan telah terdaftar di Pemerintah Daerah setempat serta bukan organisasi sayap partai politik. Adapun ormas keagamaan yang hadir dari agama Islam seperti Nahdatul Ulama (NU), Persatuan Tarbiyah (Perti), Muhammadiyah dan Majelis Ulama Indonesia (MUI), Kakanmenag, selanjutnya ormas keagamaan dari agama Kristen seperti HKBP (Huria Kristen Batak Protestan) dan GPIB (Gereja Protestan di Indonesia bagian Barat). Kegiatan ini sebagai wadah untuk saling berbagi pandangan antara pemuka agama yang menghasilkan kesepahaman bahwa kerukunan umat beragama di Pasaman Barat adalah sebuah kebutuhan. Selain itu untuk menampung aspirasi dari ormas-ormas keagamaan mengenai kerukunan umat beragama di Pasaman Barat. Tujuannya untuk meningkatkan sikap saling memahami, menerima, mengembangkan kebersamaan, 
saling menghormati dan saling percaya antar umat beragama di Pasaman Barat.

"Sekali setahun $\begin{array}{r}\text { kami } \\ \text { melakukan }\end{array}$
menampung aspirasi dari
ormas-ormas keagamaan di
Pasaman Barat, dimana
dihadiri oleh ormas-ormas
seperti NU, Perti,
Muhammadiyah, MUI, HKBP,
dan GPIB. Kegiatan ini kami
laksanakan di Aula Kantor
Bupati Pasaman Barat".

Menerima aspirasi dari ormas keagamaan menjadi agenda tahunan FKUB Pasaman Barat. Kegiatan ini dilakukan di Aula Kantor Bupati Pasaman Barat dan berlangsung selama satu hari dari pagi jam $09.00 \mathrm{Wib}$ sampai sore jam 16.00Wib. Adapun penyelenggaranya adalah pihak Kesbangpol karena anggaran untuk kegiatan FKUB Pasaman Barat bersumber dari pihak Kesbangpol. Menampung dan menyalurkan aspirasi ormas keagamaan ini tidak hanya terbatas pada agenda tahunan tetapi juga berlaku saat penyelesaian konflik di lapangan terjadi. FKUB Pasaman Barat menampung aspirasi dari ormas-ormas keagamaan seperti penolakan pendirian rumah ibadah yang dianggap tidak memenuhi syarat sehingga pada akhirnya pendirian rumah ibadah diberhentikan atau tidak boleh dilanjutkan kembali. Ini merupakan salah satu bentuk penyaluran aspirasi ormas keagamaan oleh FKUB Pasaman Barat.

Bentuk penampungan dan penyaluran aspirasi ormas keagamaan yang lain seperti demo yang terjadi pada 21 Februari 2017 di Kantor Bupati Pasaman Barat yang juga merupakan salah satu bentuk aspirasi ormas keagamaan dari Agama Islam yang diterima oleh FKUB Pasaman Barat. FKUB Pasaman
Barat menyalurkan aspirasi tersebut dengan cara melakukan rapat yang dihadiri oleh beberapa pihak terkait diantaranya Bupati $\mathrm{H}$ Syahiran sebagai pemimpin rapat, ketua FKUB Sumbar Yulius Said, Wakapolres Kompol Sukirman, Deflaizar (FKUB Sumbar), wakil ketua FKUB Pasaman Barat Suharjo Lubis, Zawil Huda (sekretaris FKUB) Pasaman Barat, Kaban Kesbangpol Edi Murdani, Kesbangpol Pemprov Sumbar, perwakilan masyarakat Giri Maju, ketua KAN Syamsul Bayan, Kasat Pol PP Edison Zalmi, Pendeta Marikon Simbolon, pimpinan TNI dan sejumlah perwakilan warga di Balkon Kantor Bupati Pasaman Barat. Hasilnya adalah menghentikan sementara pendirian rumah ibadah gereja di Nagari Giri Maju Kecamatan Luhak Nan Duo karena belum memenuhi persyaratan sesuai dengan aturan.

Selain dalam bentuk pertemuan, menampung aspirasi ormas keagamaan juga dilakukan melalui Telepon, SMS dan media sosial seperti WhatsApp. Pengurus FKUB Pasaman Barat mempunyai grup WhatsApp yang berfungsi sebagai wadah untuk berdiskusi, menampung aspirasi dan berbagi informasi terkait tentang isu-isu keagamaan yang terjadi dalam masyarakat. Selain itu grup WhatsApp juga sebagai wadah untuk mengatur kegiatan dialog baik dengan tokoh agama maupun juga tokoh masyarakat. Grup WA terdiri dari 2 buah grup, grup pertama anggotanya adalah pengurus FKUB Pasaman Barat dan grup kedua anggotanya adalah pengurus FKUB, tokoh masyarakat, ormas keagamaan, pimpinan lembaga dan instansi pemerintahan. Dalam pemanfaatannya, ketika salah satu pengurus ormas keagamaan menyaksikan atau mendapat laporan mengenai persoalan agama maka pengurus tersebut melaporkannya kepada pengurus FKUB Pasaman Barat melalui telepon, sms atau WA.

11 Suharjo, Wawancara Pribadi, Selasa

17 Juli 2018. 


\section{Menampung dan Menyalurkan Aspirasi Masyarakat}

Konflik di tengah masyarakat yang majemuk, apalagi majemuk keyakinan sangatlah rentan untuk terjadi, FKUB Pasaman Barat sebagai lembaga yang dipercaya untuk menciptakan kerukunan umat beragama berkewajiban melakukan pencegahan konflik agama yang berkepanjangan. Oleh karena itu perlu adanya antisipasi seperti membuka pusat pengaduan dan laporan dari masyarakat. $\mathrm{Hal}$ ini sudah dijalankan oleh FKUB Pasaman Barat. Berbekal keterkenalan para pengurus dengan banyak masyarakat, sehingga mempermudah masyarakat kepada siapa akan melaporkan jika terjadi pertentangan di tengah masyarakat. Hal ini merupakan hasil dari pelaksanaan sosialisasi SKB dua Menteri No.9 dan No. 8 tahun 2006 oleh pengurus FKUB Pasaman Barat terhadap tokoh masyarakat.

Dalam menjalankan tugas sebagai penampung dan penyalur aspirasi masyarakat, FKUB Pasaman Barat menerima pengaduan dari masyarakat mengenai isu-isu keagamaan pengurus FKUB Pasaman Barat memanfaatkan media sosial seperti WhatsApp, Telepon dan SMS.. Dalam pemanfaatannya, ketika masyarakat mengetahui adanya persoalan agama yang terjadi seperti misalnya pendirian rumah ibadah maka masyarakat menghubungi langsung tokoh masyarakat maupun pengurus FKUB Pasaman Barat yang mereka kenali. Setelah tokoh masyarakat maupun pengurus FKUB mendapat pengaduan dari masyarakat tersebut maka informasi yang diterima akan langsung dibagikan di grup WhatsApp baik grup sesama pengurus maupun grup dengan tokoh masyarakat dan instansi terkait. Pengurus FKUB Pasaman Barat yang terdapat dalam grup WA akan menanggapi langsung dan mengatur waktu pertemuan baik untuk pertemuan sesama pengurus terlebih dahulu maupun langsung turun ke lapangan.
"Pengurus FKUB Pasaman Barat mempunyai grup WA.Sebagai sebuah forum kerukunan umat beragama, kami menerima pengaduan atau laporan dari masyarakat mengenai persoalan agama yang terjadi di tengah masyarakat.Pengaduan itu bisa bersifat langsung menemui pengurus atau melalui media sosial seperti WA. Ketika salah satu dari pengurus mendapat laporan maka akan dishare di grup whatsapp. Dengan demikian semua pengurus akan langsung mengetahui persoalan apa yang terjadi di tengah masyarakat Pasaman Barat dan bisa berkoordinasi langsung mengenai penyelesaiannya, contohnya waktu untuk turun ke lapangan". ${ }^{12}$

Salah satu contoh aspirasi yang diterima oleh pengurus FKUB Pasaman Barat dari masyarakat adalah pendirian rumah ibadah dimana rumah salah satu jamaat (Kristen) di sulap menjadi rumah ibadah pada tahun 2014 di Kecamatan Kinali Kabupaten Pasaman Barat. Aktifitas peribadatan tersebut meresahkan masyarakat disekitar rumah ibadah sehingga masyarakat memberikan peringatan kepada Jamaat untuk tidak melanjutkan aktifitas peribadatan. Memberikan peringatan telah dilakukan berkali-kali oleh masyarakat kepada Jamaat namun tidak ditanggapi sehingga terjadinya pembakaran rumah ibadah tersebut. Penyampaian aspirasi ini dilakukan oleh salah satu warga dengan cara menemui pengurus FKUB Pasaman Barat.

Setelah mendapatkan pengaduan dari warga terkait persoalan agama yang terjadi di tengah masyarakat Pasaman Barat, FKUB Pasaman Barat melakukan investigasi.

\section{Melakukan Investigasi}

Investigasi adalah upaya penelitian, penyelidikan, pengusutan, pencairan, pemeriksaan dan pengumpulan data, informasi

${ }^{12}$ Eufrasia, Wawancara Pribadi, Kamis 12 Juli 
dan temuan lainnya untuk mengetahui/ membuktikan kebenaran atau bahkan kesalahan sebuah fakta yang kemudian menyajikan kesimpulan atas rangkaian temuan dan susunan kejadian. Dalam menciptakan kerukunan umat beragama, FKUB Pasaman Barat melakukan investigasi dengan cara yang pertama; FKUB Pasaman Barat menerima laporan dari masyarakat bahwa telah terjadi pertentangan antar pemeluk agama di suatu tempat. Salah satu contohnya pendirian rumah ibadah dimana rumah salah satu jamaat (Kristen) di sulap menjadi rumah ibadah pada tahun 2014 di Kecamatan Kinali Kabupaten Pasaman Barat. Aktifitas peribadatan tersebut meresahkan masyarakat disekitar rumah ibadah sehingga masyarakat memberikan peringatan kepada Jamaat untuk tidak melanjutkan aktifitas peribadatan. Memberikan peringatan telah dilakukan berkali-kali oleh masyarakat kepada Jamaat namun tidak ditanggapi sehingga terjadinya pembakaran rumah ibadah tersebut. Berdasarkan kasus yang terjadi tersebut FKUB Pasaman Barat menerima laporan dari masyarakat. Dalam menanggapi kasus tersebut FKUB Pasaman Barat dengan cepat langsung melakukan koordinasi sesama pengurus yang berlatarbelakang para tokoh agama. Setelah itu, koordinasi antar pengurus FKUB selesai, maka upaya koordinasi akan dilebarkan kepada instansi lain, seperti pihak kepolisian, pihak pemerintah daerah yang diwakili dinas Kesbangpol (Kesatuan Bangsa dan Politik) dan pihak Kakanmenag (Kepala kantor Kementrian Agama) Kab. Pasaman Barat.

Pengurus FKUB Pasaman Barat beserta intansi-instansi terkait melakukan koordinasi di Aula Kantor Bupati Pasaman Barat. Koordinasi bertujuan untuk membahas laporan yang diterima dari masyarakat yakni pertentangan konflik antar agama. Semua pihak diminta untuk memberikan informasi yang diterima dari masyarakat mengenai konflik agama yang terjadi. Dalam proses koordinasi semua pihak mengatur dan menetapkan mekanisme penyelesaian konflik yang akan dilakukan di lapangan. Artinya, mekanisme penyelesaian konflik yang akan dilakukan di lapangan merupakan hasil kesepakatan bersama semua pihak baik pengurus FKUB Pasaman Barat, pihak kepolisian, pihak pemerintah daerah dan pihak kementerian agama Pasaman Barat. Setelah koordinasi selesai, maka dihasilkanlah langkahlangkah yang akan dilakukan ke lokasi kejadian dan tentu dalam rangka mencari informasiinformasi konkret yang melatarbelakangi kejadian itu terjadi.

Langkah yang dilakukan pengurus FKUB Pasaman Barat dan instansi-instansi terkait adalah pemeriksaan atau penyelidikan langsung ke lapangan berdasarkan laporan yang telah diterima dari masyarakat. Pemeriksaan yang dilakukan meliputi penyebab terjadinya konflik antar agama, siapa saja yang terlibat serta dampak yang terjadi akibat adanya konflik.

\section{Melakukan Mediasi}

Mediasi adalah upaya penyelesaian konflik dengan melibatkan pihak ketiga yang netral, yang tidak memiliki kewenangan mengambil keputusan yang membantu pihak-pihak yang bersengketa mencapai penyelesaian (solusi) yang diterima oleh kedua belah pihak. Selain investigasi, mediasi juga merupakan cara yang dilakukan dalam penyelesaian konflik antar umat beragama di Pasaman Barat. Berdasarkan konflik agama yang terjadi di Pasaman Barat seperti salah satunya keresahan yang dialami oleh masyarakat akibat adanya pendirian rumah ibadah oleh Agama Kristen, FKUB Pasaman Barat berperan sebagai mediator dalam penyelesaian konflik yang terjadi. Selain itu juga melibatkan instansi-instansi lain seperti pihak kepolisian, pihak pemerintah daerah yang diwakili dinas Kesbangpol (Kesatuan Bangsa dan Politik) dan pihak Kakanmenag 
(Kepala kantor Kementrian Agama) Kab. Pasaman Barat.

Dalam proses mediasi pengurus FKUB Pasaman Barat beserta instansi-instansi terkait langsung turun ke lapangan untuk menyelesaikan konflik yang terjadi. Adapun caranya dengan mempertemukan kedua belah pihak yang bersengketa, contohnya masyarakat dan pihak yang mendirikan rumah ibadah. FKUB Pasaman Barat meminta aspirasi dari kedua belah pihak, kemudian mengakomodir semua aspirasi dari kedua belah pihak. FKUB Pasaman Barat berupaya mencarikan solusi mengenai kasus pendirian rumah ibadah dan menjelaskan peraturan pemerintah terkait tentang pendirian rumah ibadah yakni Surat Keputusan Bersama (SKB) dua mentri no 9 dan no 8 tahun 2016. Adapun peraturannya seperti: daftar nama dan Kartu Tanda Penduduk (KTP) pengguna rumah ibadat paling sedikit 90 orang yang disahkan oleh pejabat setempat sesuai dengan tingkat batas wilayah, dukungan masyarakat setempat paling sedikit 60 orang yang disahkan oleh Lurah/Kepala Desa/Wali Nagari, rekomendasi tertulis kepala kantor departemen agama kabupaten/kota dan rekomendasi tertulis FKUB kabupaten/kota.

Berdasarkan mediasi yang dilakukan oleh FKUB Pasaman Barat dan instansi-instansi terkait, adapun bentuk hasil kesepakatan yang diperoleh adalah aktifitas peribadatan tidak dilanjutkan lagi. Solusi ini diambil sebagai tanggapan dari keresahan masyarakat. Rumah ibadah yang mulai dibangun yang tidak memenuhi aturan sesuai dengan peraturan SKB dua mentri diberhentikan. Langkahlangkah ini disepakati adalah dalam rangka untuk menciptakan keadilan dan kerukunan antar umat beragama di Pasaman Barat.

Dalam teori struktural fungsional Talcott Parsons mengenai prasyarat fungsional, kegiatan-kegiatan atau aktifitas-aktifitas seperti melakukan dialog dengan tokoh agama dan tokoh masyarakat, menampung dan menyalurkan aspirasi organisasi kemasyarakatan serta menampung dan menyalurkan aspirasi masyarakat termasuk kepada fungsi integrasi. Aktifitas-aktifitas tersebut merupakan upaya pemerintah Pasaman Barat menyatukan berbagai elemen agar tercapainya visi Pasaman Barat untuk menciptakan masyarakat yang beriman dan bermartabat yang salah satu indikatornya dilihat dari kerukunan antar umat beragama di Pasaman Barat. Aktifitas-aktifitas yang dilakukan FKUB Pasaman Barat berdasarkan tugas FKUB kabupaten yang terdapat dalam SKB 2 Menteri No.9 dan No.8 tahun 2006.

\section{Kesimpulan}

FKUB Pasaman Barat semenjak didirikan pada Tahun 2007 melalui Surat Keputusan (SK) Bupati Pasaman Barat No. 188.45/04/BUP-PASBAR/2007 ditugasi sebagai lembaga yang mampu mewujudkan kerukunan umat beragama di Pasaman Barat, artinya FKUB Pasaman Barat bertanggungjawab menyelesaikan persoalan-persoalan agama yang terjadi di tengah kemajemukan masyarakatnya. Hingga saat ini ada beberapa aktivitas-aktivitas yang teah dilakukan FKUB baik tindakan pencegahan terjadinya persoalan agama atau penanganan persoalan yang telah terjadi. Diantaranya adalah melakukan dialog dengan tokoh agama dan tokoh masyarakat, menampung dan menyalurkan aspirasi organisasi kemasyarakatan, menampung dan menyalurkan aspirasi masyarakat, melakukan investigasi dan melakukan mediasi terhadap konflik yang terjadi.

Dalam pelaksanaan aktifitas-aktifitas tersebut, FKUB ikut melibatkan pihak-pihak terkait, seperti Dinas Kesbangpol, Kakanmenag, Kepolisian, Dandim, Ormas, Tokoh Agama dan Tokoh Masyarakat. Pihakpihak tersebut bekerjasama dengan FKUB 
untuk saling bersinergis mewujudkan kerukunan beragama di Pasaman Barat.

\section{Daftar Pustaka}

\section{Buku Teks}

BPS Pasaman Barat. 2017. Pasaman Barat dalam Angka (Padang: CV. Zigiran).

Faisal. 2016. Hubungan Antar Agama; Hubungan Islam Kristen Menurut Muhammad Natsir. (Padang: Hayfa Press).

Harahap, Syahrin. 2011. Teologi Kerukunan Jakarta: Prenada.

Nasikun. 2014. Sistem Sosial Indonesia. (Jakarta: RajaGrafindo Persada).

Raharjo, M. Dawam. 2010. Merayakan Kemajemukan Kebebasan dan Kebangsaan (Jakarta: Kencana).

Setiadi, Elly M dan Kolip, Usman. 2011. Pengantar Sosiologi "Pemahaman Fakta dan Gejala Permasalahan Sosial: Teori, Aplikasi dan Pemecahannya. (Jakarta: Kencana Prenada Media Goup).

\section{Jurnal}

Syukron, Buyung, Agama dalam Pusaran Konflik, Studi Analisis Resolusi terhadap Munculnya Kekerasan Sosial Berbasis Agama di Indonesia, Ri'ayah, Vol. 02, No.01 Januari-Juni 2017, h. 710.

\section{Referensi Wawancara}

Alam, Alman Gampo, Wawancara Pribadi, Kamis 24 Agustus 2017.

Eufrasia, Wawancara Pribadi, Kamis 12 Juli 2018

Suharjo, Wawancara Pribadi, Selasa 17 Juli 2018.

Yondrizal, Wawancara Pribadi, Minggu 8 Juli 2018. 